\title{
Facies Analysis and Depositional Environment of Upper Permian Rocks in Darin Section, East-Central Iran
}

\section{Bibi Haniyeh Emraninasab', Mohammad Hossein Adabi2 ${ }^{2}$ Mahmood Reza Majidifard ${ }^{3}$, Nader Kohansal Ghadimvand ${ }^{*}$, Sohei Erfani1 ${ }^{1}$}

\author{
${ }^{1}$ Department of Geology, Islamic Azad University, North Tehran Branch, Tehran, Iran \\ ${ }^{2}$ Department of Earth sciences, Shahid Beheshti University, Tehran, Iran \\ ${ }^{3}$ Research Institute for Earth Sciences, Geology Survey of Iran, Tehran, Iran \\ Email: ^nkohansal@yahoo.com
}

How to cite this paper: Emraninasab, B.H., Adabi, M.H., Majidifard, M.R., Ghadimvand, N.K. and Erfani, S. (2017) Facies Analysis and Depositional Environment of Upper Permian Rocks in Darin Section, East-Central Iran. Open Journal of Geology, 7, 242-256.

https://doi.org/10.4236/ojg.2017.73017

Received: January 2, 2017

Accepted: March 18, 2017

Published: March 21, 2017

Copyright $\odot 2017$ by authors and Scientific Research Publishing Inc. This work is licensed under the Creative Commons Attribution International License (CC BY 4.0).

http://creativecommons.org/licenses/by/4.0/

\begin{abstract}
Deposits of Permian rocks in Kalmard Block are recognized with Khan Group, showing various characteristics in different outcrops. This group is made up of three informal formations, namely Chili, Sartakht and Hermez. Upper Permian deposits (Hermez Formation) are composed chiefly of lateritic and carbonate rocks. This formation is composed of $65.5 \mathrm{~m}$ lateritic soils, lateritic sandstone, limestone, dolomite and dolomitic limestone in the Darin section. This formation unconformably overlies middle Permian siliciclastic and evaporite deposits (Sartakht Formation), where as it is depicted underlying an erosional unconformity above lateritic deposits of lower Triassic (Sorkh Shale Formation). According to lithologic and microscopic investigations, the deposits of Hermez Formation can be divided into 1 siliciclastic petrofacies and 14 carbonate microfacies. Field observations, along with microscopic examinations, have resulted in identifying tidal flat, lagoon, shoal and open marine environments in the rocks of the studied formation. Vertical changes of microfacies and depth variation curve point to the high thickness of the microfacies of lagoon, tidal flat and shoal environments and low thickness of open marine microfacies. Hermez Formation rocks in Darin section are deposited in a low-angle homoclinal ramp, mostly in the inner ramp, located in the southern Paleo-Tethys Ocean.
\end{abstract}

\section{Keywords}

Upper Permian, Kalmard Block, Hermez Formation, Depositional Environment 


\section{Introduction}

Central Iran zone, shaped like a triangle and as one of the major, largest and most complex geological units in Iran, is located in the center of Iran. Structural model of this area consists of separate blocks, separated by deep faults, thereby exhibiting distinct characteristics. Kalmard Block, enjoying a northeastern trend, is situated between Kalmard faults in the east and those of Naein in the west [1].

\section{Darin Section Position}

This section is located in the west of Tabas (at 1:250000 scale) [2] and northeast of Robate-khan village in Kalmard zone (at 1:100000 scale) [3] (eastern central Iran). It is formed by geographical coordinates of 33'32"09N and 56'09'07'E, and is located about 90 kilometers from Tabas-Yazd main road, accessible by an eleven-kilometer dirt road (Figures 1-3).

\section{Methodology}

To determine the facies characteristics and depositional environment conditions

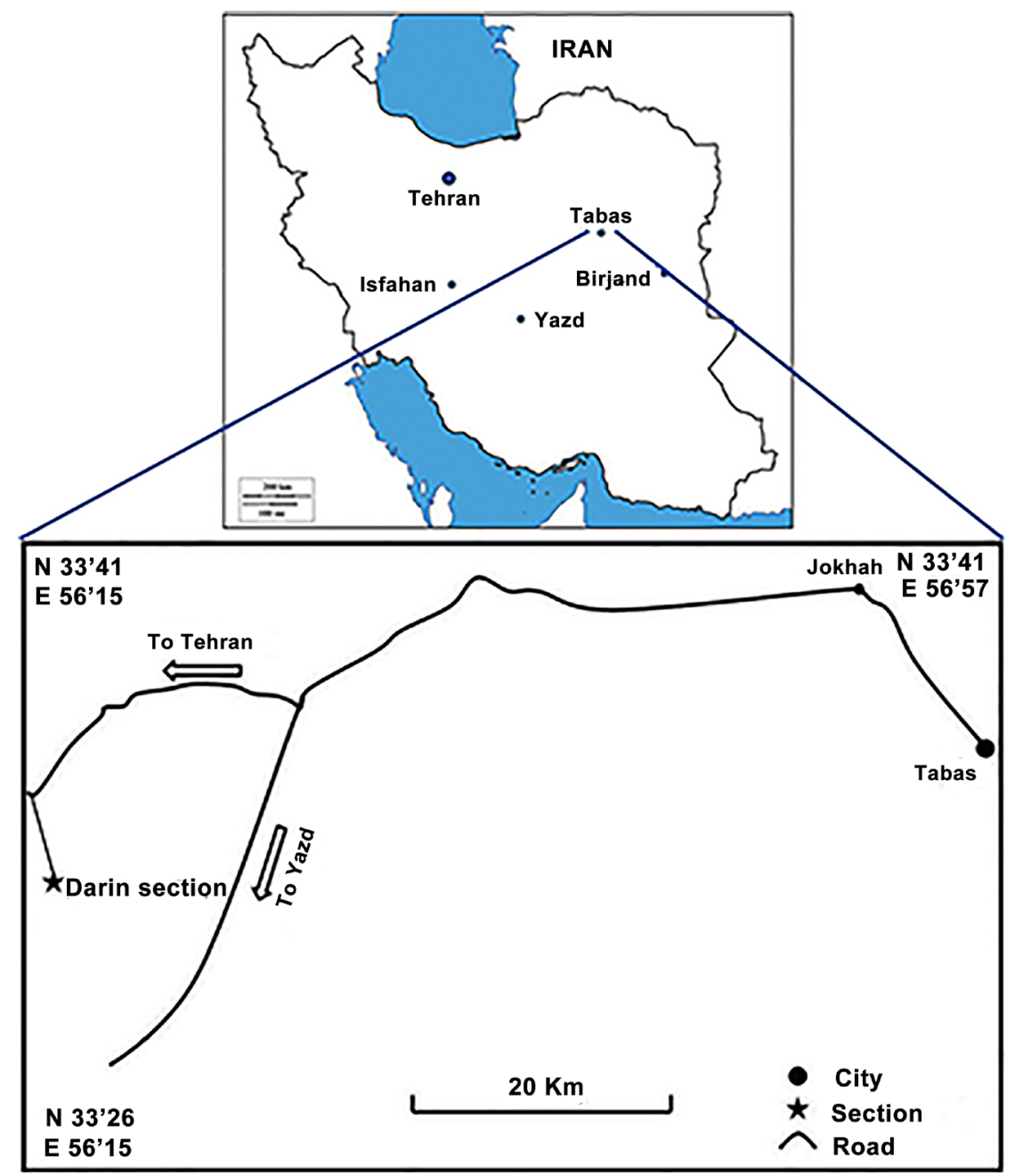

Figure 1. Geographical setting and access way to Hermez Formation in Darin section. 


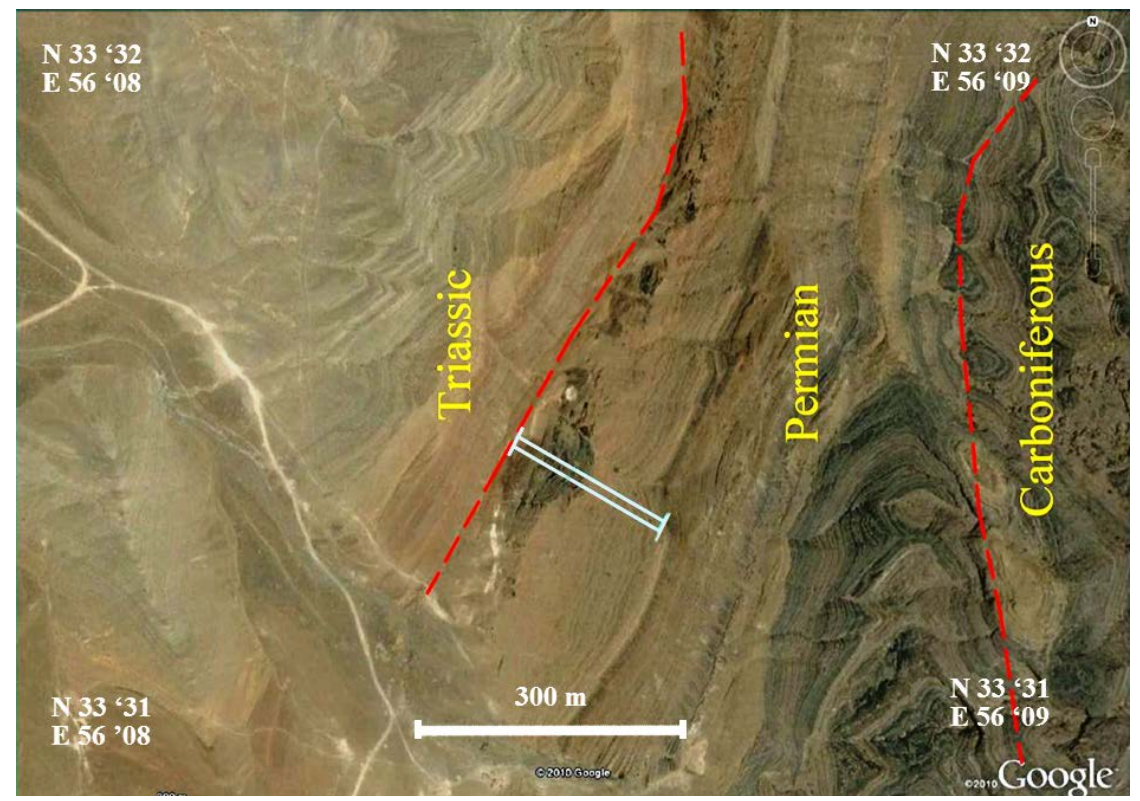

Figure 2. Satellite image of Hermez Formation in Darin section, separation of sediments age based on Tabas map (at 1:250000 scale) (Aghanabati, 1977).

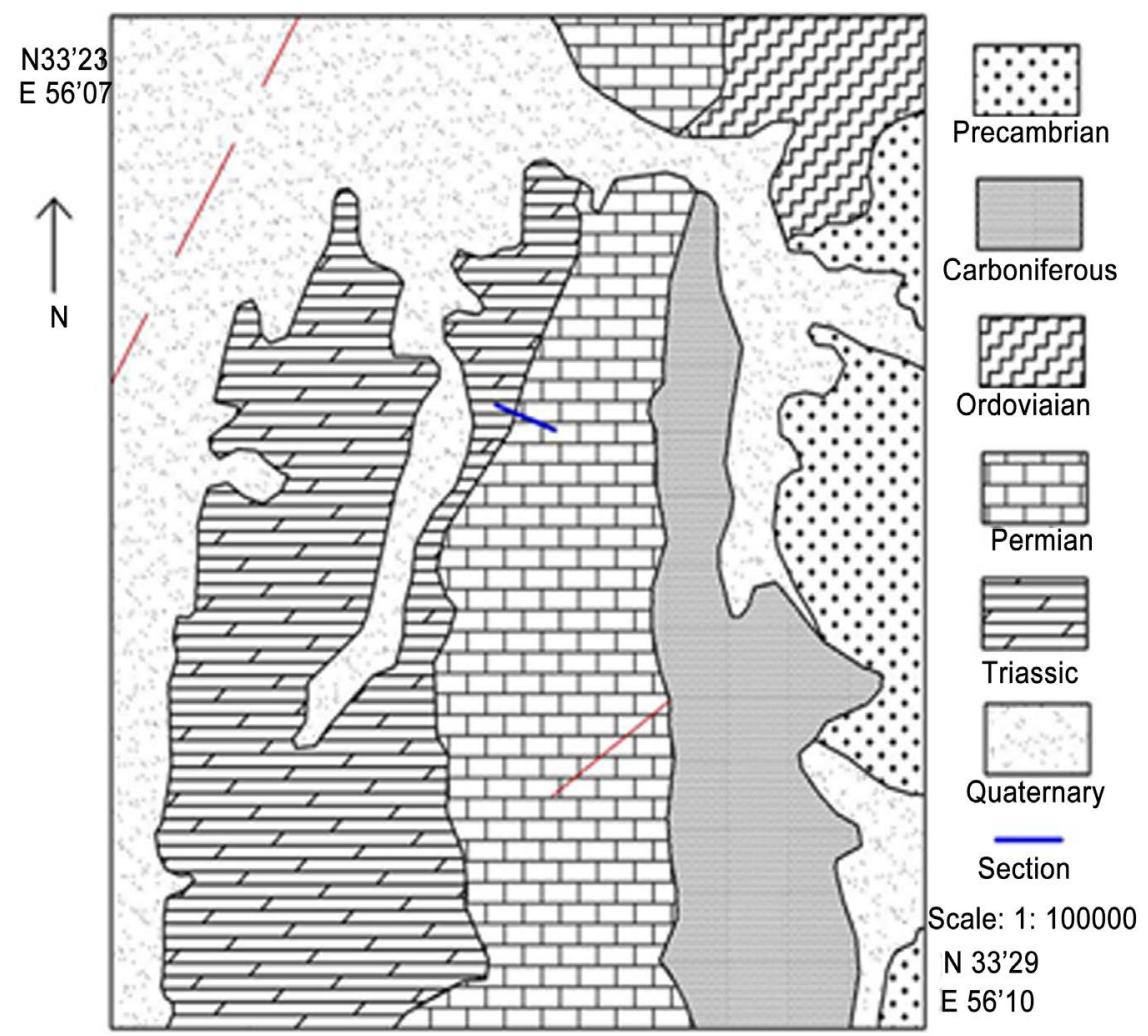

Figure 3. Geological map of Hermez Formation in Darin section (Aghanabati, 1977).

in this section, the geological maps of Tabas (at 1:250000 scale) [2] and Robate-khan (at 1:100000 scale) [3] are employed and then the required data are collected though examining literature including textbooks, papers, reports, etc. Regarding field observations, the lithological characteristics of the sequence in- 
cluding gradation, various depositional structures and various fossils are recorded. According to laboratory investigations, moreover, carbonate microscopic thin sections are used to reveal the characteristics of microscopic facies (namely, grain size and other textual features), diagenetic characteristics and microfossils. The petrofacies of siliciclastic rocks are identified by studying thin sections. Having collected data from thin sections, the depositional environment of this formation is interpreted and explained. Adopting Dickson's 1965 method, Alizarin Red $S$ is used to stain the thin sections to identify the type of carbonate minerals (distinguishing calcite from dolomite) [4]. Folk classification scheme [5] is used to classify siliciclastic petrofacies, and Dunham [6] classification system, refined by Emry \& Klovan in 1971 is employed to describe the composition of the carbonate microfacies [7]. Additionally, a comparison is made between vertical changes of microfacies and recent depositional environment using information gathered from Wilson, 1975; Carozzi, 1989; Tucker \& Wright, 1990; Flügel, 2010 [8] [9] [10] [11].

\section{Stratigraphy}

Upper Permian deposits (Dzhulfian-Dorashamian stages), composed of sandstone, limestone, dolomite and dolomitic limestone, are recognized by Hermez informal formation in Kalmard Block. One of the most comprehensive outcrops of Hermez Formation is situated in Darin section, in which deposits of Hermez Formation rocks have strike N18E, Dip 61NW and $65.5 \mathrm{~m}$ thickness. The lithology of Hermez Formation in Darin section is composed chiefly of sandstone, limestone, dolomite and dolomitic limestone, and, based on morphologic and lithologic characteristics, can be divided into six units including: a sequence of reddish, old lateritic soils and lateritic sandstone with $6 \mathrm{~m}$ in thickness (unit 1), which has unconformably overlain carbonate and siliciclastic deposits of Chili Formation (lower Permian), medium-to-thick, gray dolomitic limestone with 8.5 $\mathrm{m}$ in thickness (unit 2), medium-to-thin, yellow dolomitic limestone with $6 \mathrm{~m}$ in thickness (unit 3), a sequence of dolomitic limestone and thick-to-medium, light gray lime dolomite with $30 \mathrm{~m}$ in thickness (unit 4), thick-to-medium, reddish yellow dolomite with a thickness of $4 \mathrm{~m}$ (unit 5) and 11-meter, thick-to-medium, dark gray limestones (unit 6). The unit unconformably underlies medium-tothin, reddish sequence of shale and lateritic and oxidized siltstone belonging to Sorkh Shale Formation (Lower Triassic).

\section{Investigating the Facies and Depositional Environment of Hermez Formation in Darin Section}

Lithologic and microscopic studies reveal that this sequence consists of one siliciclastic petrofacies and fourteen carbonate microfacies. These siliciclastic petrofacies and carbonate microfacies of Hermez Formation are deposited on four facies belts including Tidal flat environment (A), Lagoon environment (B), Shoal environment (C) and Open marine environment (D). These facies belts, facing sea from the coast, include: 


\subsection{Facies Belt A: Tidal Flat Environment}

This facies belt includes one petrofacies and five microfacies. A1 is a siliciclastic petrofacies while A2 to A5 are carbonate microfacies. These petrofacies and microfacies are deposited in the supertidal and intertidal subenvironments, described as follow:

\section{A1: Sublitharenite Petrofacies}

This petrofacies involves $45 \%$ immature, well-sorted but relatively poorrounded quartz, together with $10 \%$ rock fragments with $2 \mathrm{~mm}$ in size. The average size of grains ranges from $0.3 \mathrm{~mm}$ to $2 \mathrm{~mm}$ (Figure $4(\mathrm{a})$ ).

\section{A2: Dolomitized Fenestral Gypsiferous Mudstone Microfacies}

This facies is composed of $20 \%$ gypsum crystals in $0.2 \mathrm{~mm}$ size and fenestral fabric or bird's eyes, lying within a lime mud matrix. This facies has undergone dolomitization process (Figure 4(b)).
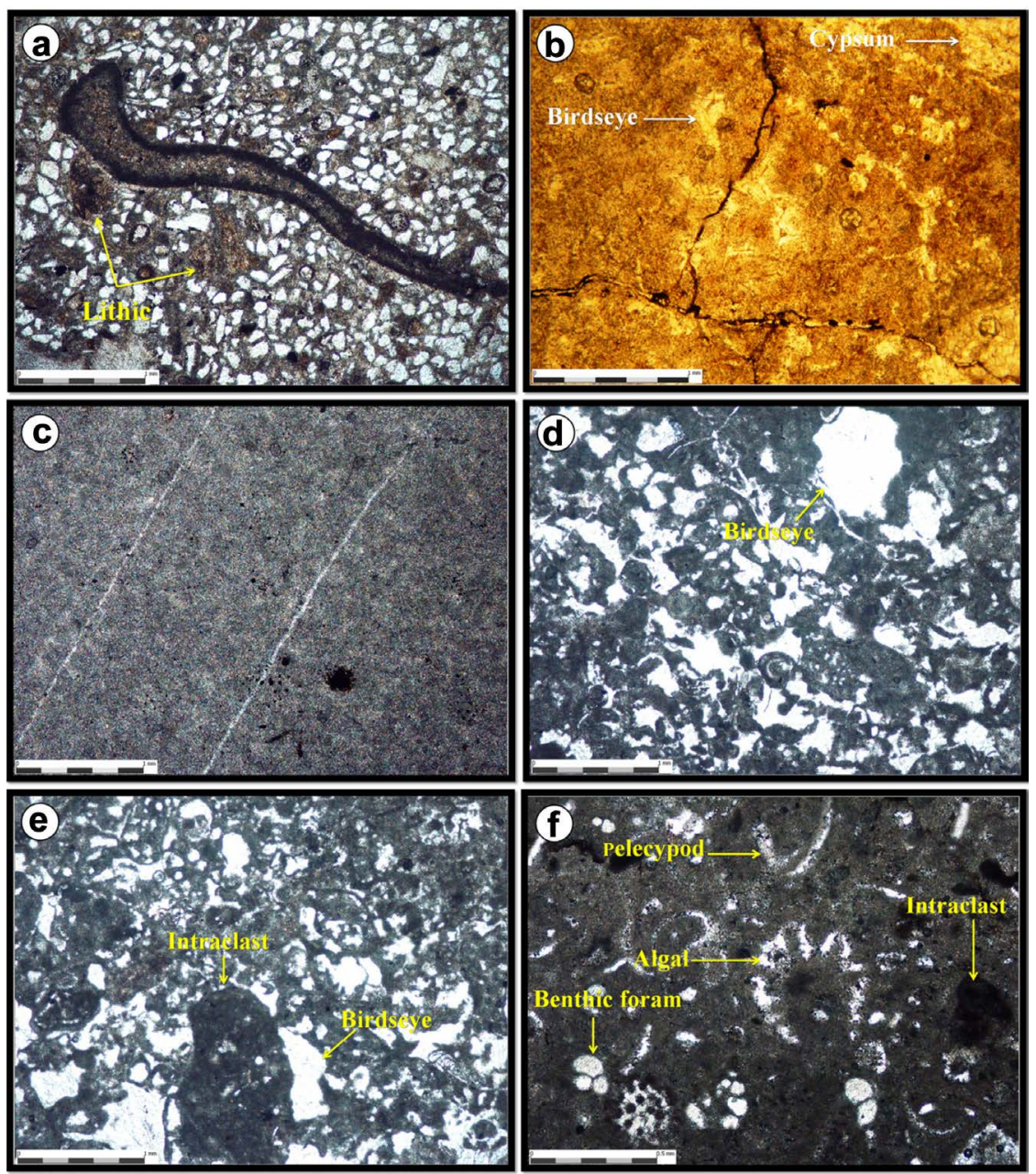

Figure 4. Carbonate microfacies and siliciclastic petrofacies of tidal flat environment in Hermez Formation, Darin section: (a) Sublitharenite petrofacies; (b) Dolomitized fenestral gypsiferous mudstone microfacies; (c) Oxidized dolomudstone microfacies; (d) Fenestral bioclast mudstone/wackstone microfacies; (e) Fenestral bioclast intraclast wackstone microfacies; (f) Fenestral benthic foraminifera intraclast pelecypod algal wackstone/ packstone microfacies. $1 \mathrm{~mm}$ scale. 


\section{A3: Oxidized Dolomudstone Microfacies}

This microfacies consists of microcrystalline dolomite or dolomicrite, oxidized by Fe (Figure 4(c)).

\section{A4: Fenestral Bioclast Mudstone/Wackstone Microfacies}

This microfacies is completely covered by $5 \%$ to $10 \%$ microcrystalline lime mud and fenestral fabric or bird's eye, intraclast and skeletal fragments (algae, benthic foraminifera, gastropod) (Figure 4(d)).

\section{A5: Fenestral Bioclast Intraclast Wackstone Microfacies}

The analysis of the structure of this microfacies shows a composition of intraclast, $10 \%$ to $15 \%$ skeletal fragments and fenestral fabric or bird's eye together with calcimicrobe algae, located within a lime mud matrix (Figure 4(e)).

A6: Fenestral Benthic Foraminifera Intraclast Pelecypod Algal Wackstone/Packstone Microfacies

This microfacies hosts benthic foraminifera with 5\% 0.2-mm-sized Globivavulina sp., $5 \%$ intraclast fragments with $0.2 \mathrm{~mm}$ in size, $5 \%$ pelecypoda with a size of $0.3 \mathrm{~mm}, 5 \%$ dasycladaceae algae with $0.3 \mathrm{~mm}$ in size and fenestral fabric and bird's eye, situated in a lime mud matrix (Figure 4(f)).

\section{Interpretation}

Petrofacies and microfacies of this group are formed in the semi-arid to arid supratidal and intertidal environments. Petrofacies A1 is a sublitharenite petrofacies, formed in the supratidal subenvironment and a warm and humid climateas a result of intense chemical weathering [12] [13].

Microfacies of this group are recognized with abundant limemud. Bird's eye or fenestral pores within the carbonate microfacies suggest deposition in tidal environment [14]. Fenestral fabric is formed as a result of losing water or burrowing activities of earthworms, and is appropriately expanded within microfaciesof this group [15] [16]. Microfacies A2 is a mudstone microfacies, composed of fenestral fabric. Lack of biological remnants and bioturbation as well as the presence of evaporite minerals and gypsum layers account for the sedimentation of this microfacies in supratidal flat environment [15] [16] and a dry and warm climate [14]. The presence of these minerals suggests an average temperature of higher than $22 \mathrm{C}$ and a seasonal temperature of more than $35 \mathrm{C}$ [9]. High rate evaporation in supratidal subenvironment causes gypsum crystals to develop, which in turn absorb calcium, thereby resulting in microcrystalline dolomicrite [17] [18]. Microfacies A3 hosts microcrystalline dolomite or dolomicrite, which are characterized as type- 1 dolomite. Its crystal size varies from 5 to 16 micron, and it is developed within a supratidal subenvironment due to the presence of microcrystals, preservation of early texture and lack of fossils. In fact, the dolomite are of secondary type, formed in the early diagenesis process. Seawater or Mg-enriched intraparticle solutions are likely to trigger dolomitization [19]. Following evaporite minerals, mudstone is formed in a supratidal subenvironment (Sabkha) in the form of early dolomite (dolomicrite). This seems generally due to the migration of sulphateions from environment [20]. The composition of bird's eye or fenestral pores together with intraclast fragments in microfacies 
A5 proves the formation of this microfacies in an intertidal subenvironment [11] [21]. Microfacies A6, accompanying supratidal microfacies and containing fenestral pores and limited lagoonal organisms, seems to be developed within an intertidal subenvironment [11].

\subsection{Facies Belt B: Lagoon Environment}

This facies belt is composed of three microfacies as follow:

\section{B1: Intraclast Benthic Foraminifera Wackstone Microfacies}

The most abundant allochem of this microfacies is $8 \%$ Globivavulina, Textularia, Earlandias, as a benthic foraminiferal species, with $0.3 \mathrm{~mm}$ in size together with $5 \% 0.2-\mathrm{mm}$-sized intraclast fragments, all located within a micritic matrix (Figure 5(a)).

\section{B2: Bioclast Intraclast Dasycladacea Packstone Microfacies}

This microfacies hosts 30\% dasycladacea algae, 30\% intraclast fragments, $20 \%$ benthic foraminifera and $10 \%$ pelecypoda fragments with $0.3 \mathrm{~mm}$ in size, all of which are located in a micritic matrix. The grain size varies from 0.2 to $1.5 \mathrm{~mm}$ in size (Figure 5(b)).

\section{B3: Gastropod Pelecypoda Wackstone Microfacies}

This microfacies shows a composition of $8 \%$ pelecypoda and $5 \%$ gastropod, all scattered within a micritic matrix. The average size of grains is $0.4 \mathrm{~mm}$ (Figure 5 (c)).

\section{Interpretation}

Microfacies of this facies belt share such characteristics as presence of lime mud, non-skeletal grains including intraclast and lagoonal bioclasts such as benthic foraminifera, dasycladacea algae, pelecypoda and gastropod, capable of surviving in restricted and semi-restricted conditions [22]. The first common characteristics among microfacies of restricted lagoon environment are the presence of tranquility in their formation environment, and the second one is the high level of salinity in the depositional environment of the sediments of this group [23]. The distinctive feature of the microfacies of this group is due to the fabric type and grain size. The high percentage of green algae (dasycladacea), foraminifera, pelecypoda and gastropoda amongst the salient features of microfacies $\mathrm{B} 1$ and $\mathrm{B} 2$ in the euphotic zone, where the water is shallow while nutrients are abundant [23] [24] [25] [26]. The high content of lime intraclast and their large size in microfacies B1 and B2 indicates that this microfacies belongs to high-energy lagoon and near shoal environments.

\subsection{Facies Belt C: Shoal Environment}

This facies belt consists of three microfacies as follow:

\section{C1: Ooid Grainstone Microfacies}

The major allochem in this microfacies is ooid, which constitutes $75 \%$ of the total sample and is $0.5 \mathrm{~mm}$ in diameter. The core of some ooids is composed of crinoid (Figure 6(a)).

C2: Sandy Bioclast Ooid Extraclast Grainstone Microfacies 

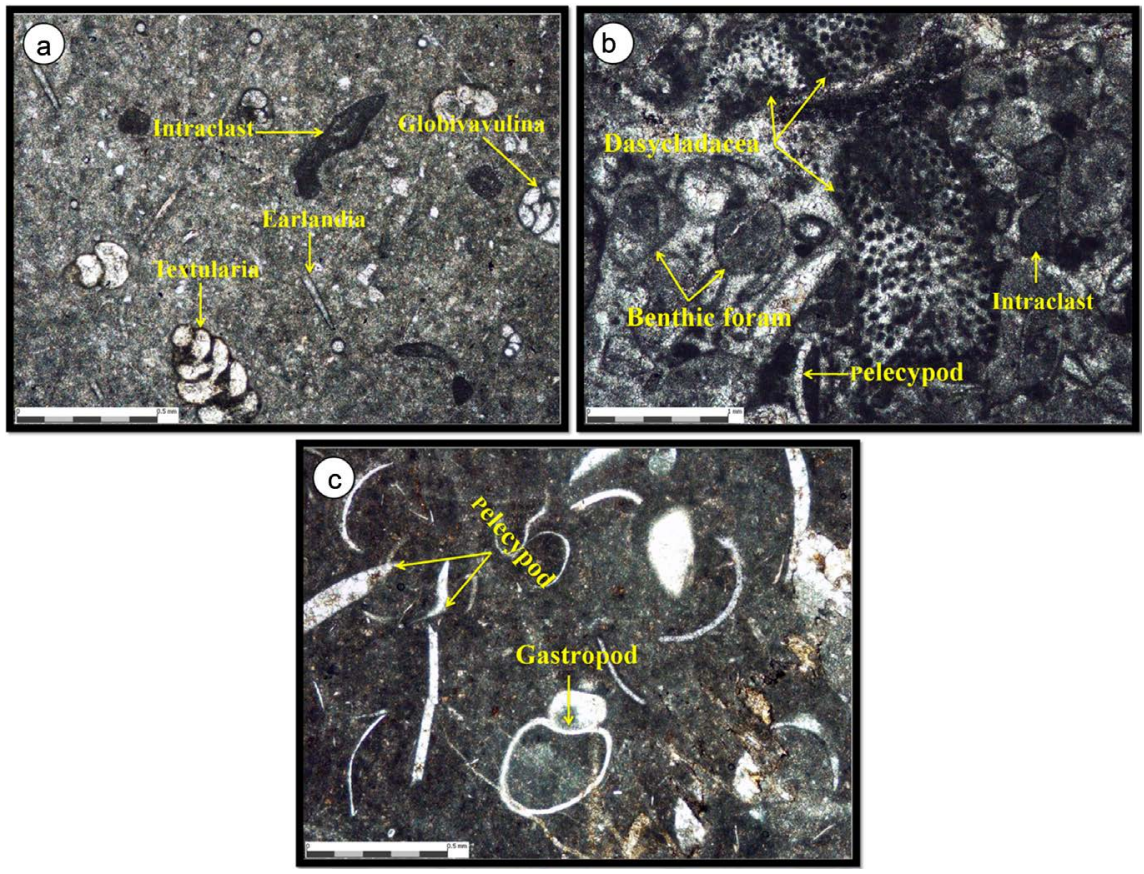

Figure 5. Carbonate microfacies of lagoon environment in Hermez Formation, Darin section: (a) Intraclast benthic foraminifera wackstone microfacies; (b) Bioclast intraclast dasycladacea packstone microfacies; (c) Gostropod pelecypoda wackstone microfacies. 1 mm scale.
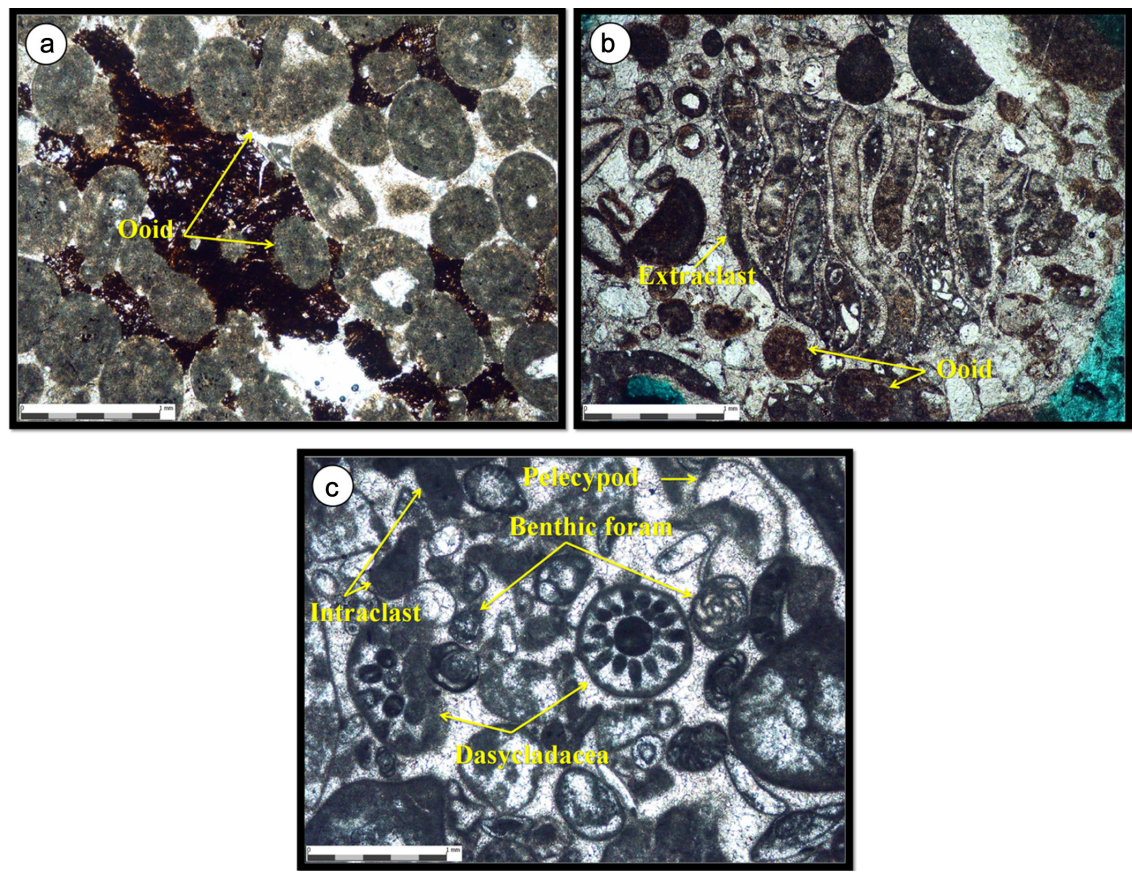

Figure 6. Carbonate microfacies of shoal environment in Hermez Formation, Darin section: (a) Ooid grainstone microfacies; (b) Sandy bioclast ooid extraclast grainstone microfacies; (c) Bioclast bryozoan grainstone microfacies. $1 \mathrm{~mm}$ scale.

This microfacies is composed chiefly of $35 \%$ intraclast. $15 \%$ concentric ooids, $5 \%$ bioclast fragments and $10 \%$ quartz grains are among other allochems of this 
microfacies. The average size of the grains ranges from 0.2 to $3.5 \mathrm{~mm}$ (Figure $6(b))$.

\section{C3: Bioclast Bryozoan Grainstone Microfacies}

This microfacies hosts various bioclast fragments including $40 \%$ crinoids with $1 \mathrm{~mm}$ in size, $10 \%$ intraclast with $0.4 \mathrm{~mm}$ in size and $15 \%$ medium-sorted and rounded quarts grains, located in a micritic matrix (Figure 6(c)).

\section{Interpretation}

This facies belt is formed in high-energy shoal setting and below the wave effect due to the presence of non-skeletal fragments such as ooid, intraclast and extraclast and lack of limemud [27]. The presence of fully cement matrix, lack of limemud and size of the grains forming these microfacies indicate the high level of energy during the formation of this microfacies in a shoal environment [28] [29] [30]. The abundance of ooids and cross and plate lamination in microfacies $\mathrm{C} 1$ points to association of this microfacies with a high-energy and shallow environment like shoal [31] [32]. Cross lamination mostly found in mediumgrained sediments suggests a high-energy condition during the formation of this microfacies [21]. Similarly, a microfacies with medium to well sorted and rounded ooids is formed in the depositional environments of current age like southern coasts of Persian Gulf and the Bahamas at a depth of lower than $5 \mathrm{~m}$. the presence of rounded intraclast in microfacies $\mathrm{C} 2$ indicates the high-energy and turbulent part of shoal environment [10]. According to the evidence, this microfacies can be associated with the outermost part of carbonate shoal, i.e. seaward shoal [10] [11] [33] [34]. Microfacies C3 consists of lagoonal skeletal fragments like benthic foraminifera, scattered in a sparite matrix. The evidence indicates that this microfacies is developed in a leeward shoal environment [8]. In this microfacies, moreover, intraclasts result from erosion and rip-up as well as erosion of older deposits by stormy currents [35].

\subsection{Facies Belt D: Open Marine Environment}

This facies belt is composed of three microfacies as follow:

\section{D1: Ostracod Wackstone Microfacies}

This microfacies includes $10 \% 0.1$ to 0.2 -mm-sized ostracod and 3\% 0.1-mmsized radiolarian, located in a dark micritic matrix (Figure 7(a)).

D2: Dolomitized Archaeodiscus Radiolarian Wackstone/Packstone Microfacies

This microfacies contains $30 \%$ radiolarian with $0.1 \mathrm{~mm}$ in size and $10 \%$ archaediscus with $0.3 \mathrm{~mm}$ in size, all scattered within a micritic matrix. It is noteworthy that dolomitization has influenced this microfacies (Figure 7(b)).

\section{D3: Sandy Intraclast Bioclast Packstone Microfacies}

The composition of this microfacies shows various bioclast fragments including 40\% 1-mm-sized crinoid, 10\% 0.4-mm-sized intraclast and 15\% mediumsorted and rounded quartz grains, located in a micritic matrix (Figure $7(\mathrm{c})$ ).

\section{Interpretation}

The intergranular muddy matrix [36] and abundance of radiolarian and os- 

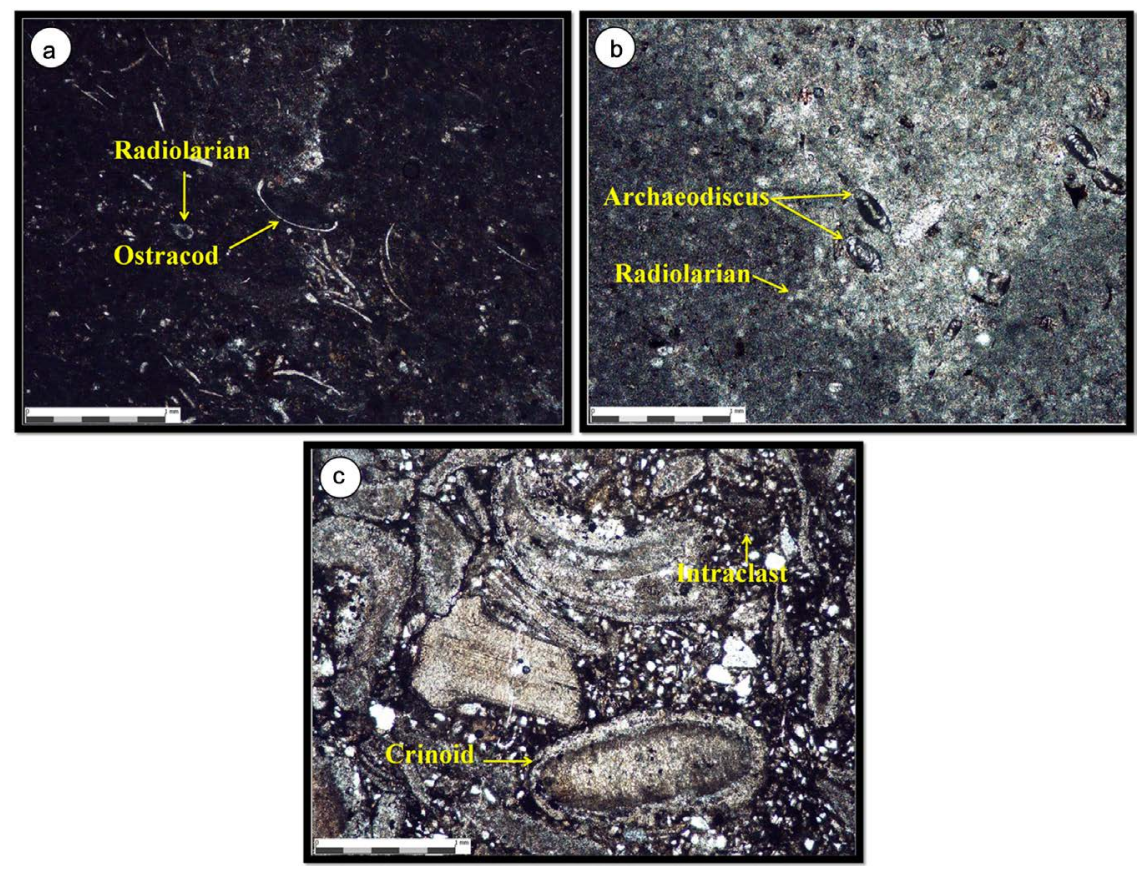

Figure 7. Carbonate microfacies of open marine environment of Hermez Formation in Darin section: (a) Ostracod wackstone microfacies; (b) Dolomitized archaeodiscus radiolarian wackstone/packstone microfacies; (c) Sandy intraclast bioclast packstone microfacies. $1 \mathrm{~mm}$ scale.

tracod [11] point to the formation of deposits in a low-energy and calm environment like open marine. The abundance of carbonate mud and a fall in the size of skeletal fragments in microfacies D1 and D2 suggest the deposition of these microfacies within deep and low-energy open marine environment [11]. Allochem has increased whereas micrite has decreased in microfacies D3. The presence of a small amount of cement, intraclasts and bioclasts like large crinoids as well as high concentration of allochems in these microfacies indicates their formation in shallow and high-energy setting like supratidal or near shoal environments [11].

\section{Depositional Environment Model of Hermez Formation in Darin Section}

According to the microscopic and field observations, vertical relationship between microfacies and the comparison made between microfacies of Hermez Formation and current depositional microfacies, the depositional model of Hermez Formation in Darin section is presented in Figure 8. This model represents the position of the formation of siliciclastic petrofacies and carbonate microfacies of the mentioned facies in tidal flat, lagoon, shoal and open marine environments. Owning to the lack of calciturbidite, slumps, barrier reefs and oncolite as well as the presence of gradational facies, this petrofacies and its microfacies are formed in a low-angle homoclinal carbonate-siliciclastic ramp [22] [37] [38], located in the passive margin of southern Paleo-Tethys Ocean [39]. Investigating the microfacies and depositional environment of Hermez envi- 
ronment in Darin section indicates that shallow marine environment is observed in lower Permian, where various microfacies of Hermez Formation are deposited. As can be seen in the proposed model, the sublitharenite petrofacies is deposited in an oxidized supratidal subenvironment, pointing to their formation in a warm and humid climate. Fenestral and bird's-eye fabrics are common in intertidal microfacies. Deposits of lagoon environment are laid in a restricted to semi-restricted environment, separated from shoal environment by organisms like ooids, which contribute to its formation. Open marine environment is characterized by the presence of radiolaria and ostracod fragments in a limemud matrix. Its thickness is reported to be less than other environments (Figure 8).

\section{The Frequency Column of Microscopic Microfacies}

These microscopic microfacies consists of orthochem and allochem components, the type of matrix or cement and the type of skeletal and non-skeletal. The frequency percentage of allochem is computed by polarizing microscope and depicted separately for each allochem. It is noteworthy that only two samples of unit1 are studied due to their lateritic and nonremovable nature (Figure 9).

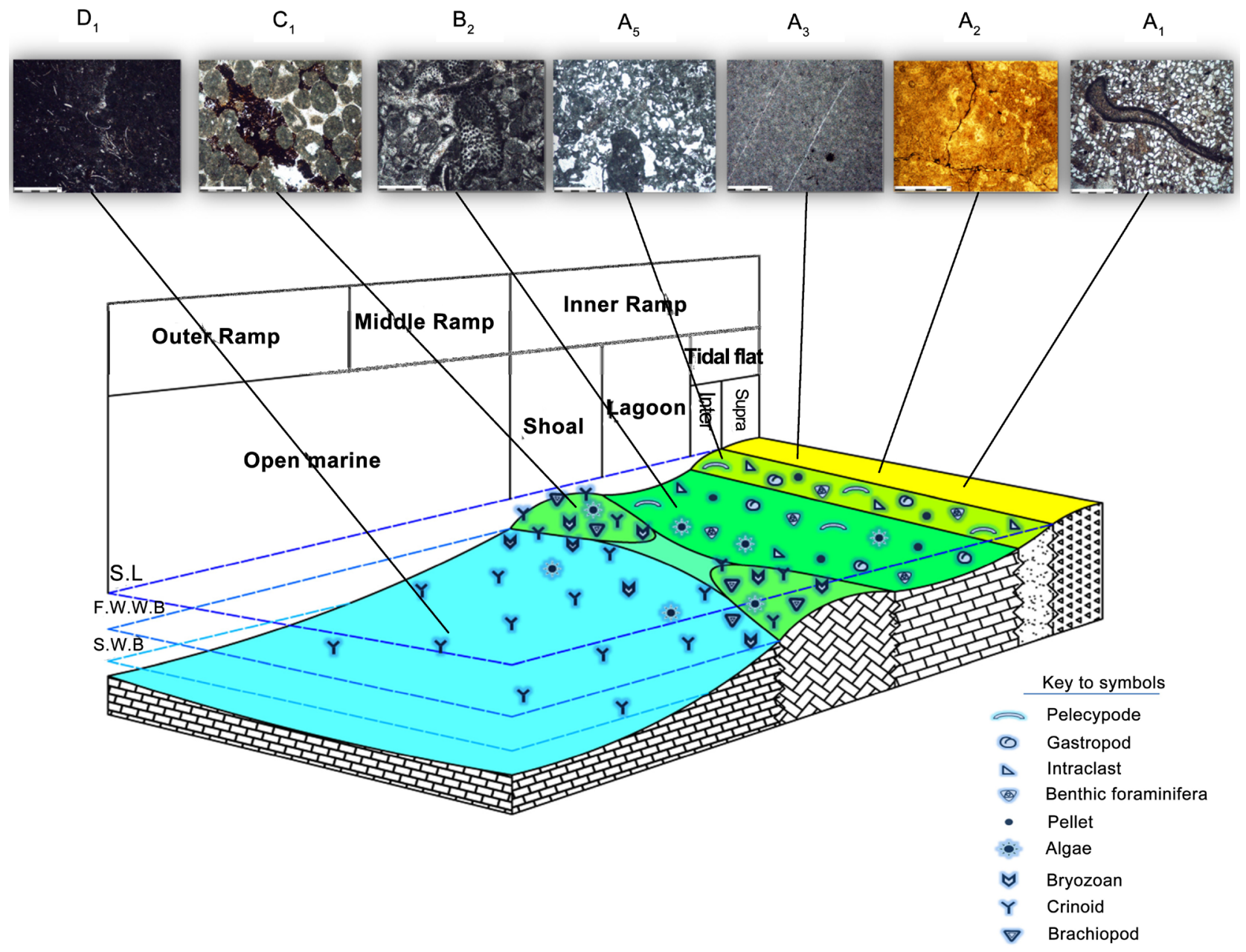

Figure 8. Depositional environment model of Hermez Formation in Darin section. 


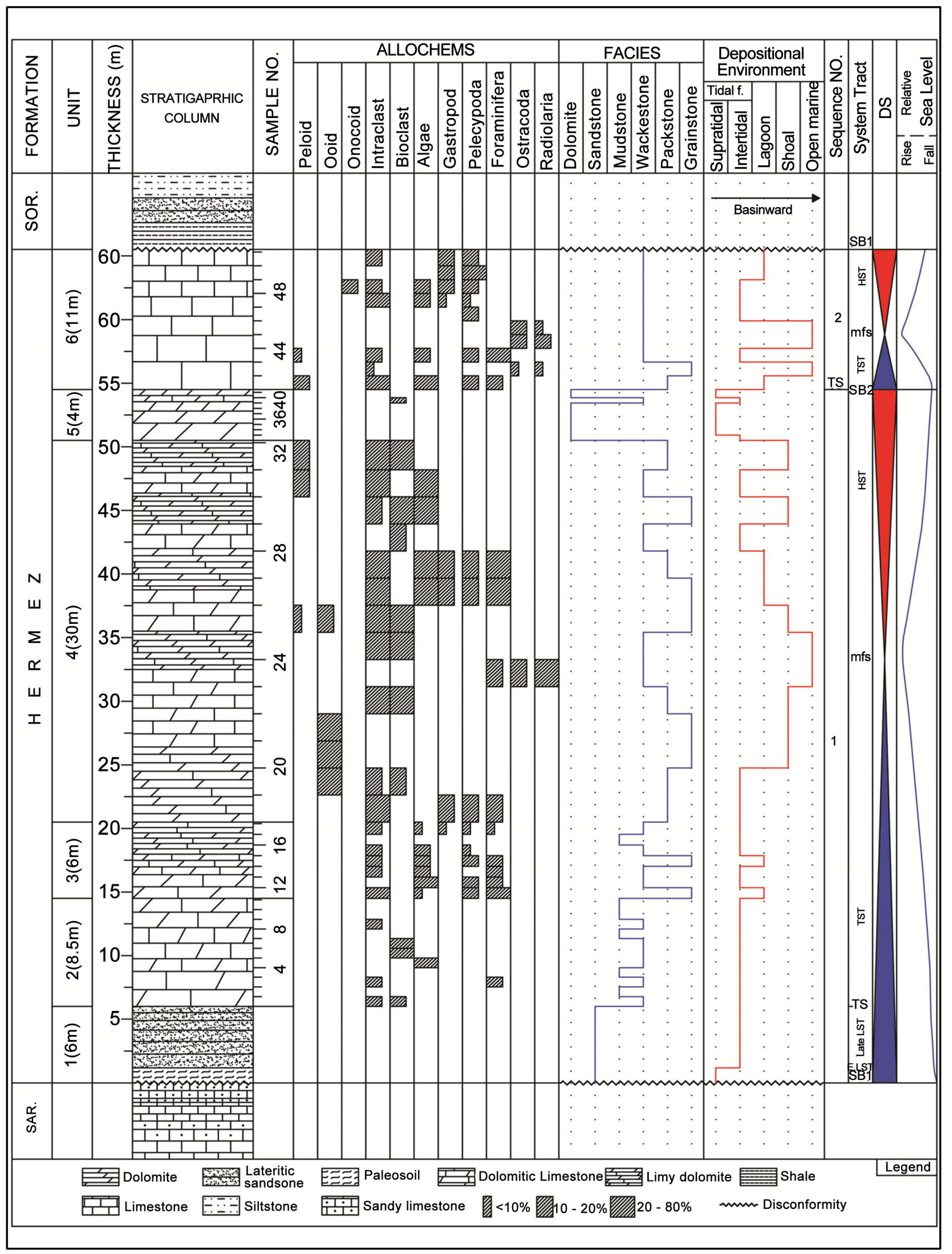

Figure 9. Frequency column of microscopic microfacies of Hermez Formation in Darin section. 


\section{Conclusions}

Having analyzed the facies, depositional environment and sequence stratigraphy of the deposits of Khan Group (Hermez Formation) in Darin section, the researchers came up with the following results:

Upper Permian rocks (Dzhulfian-Dorashamian stages) are recognized by Hermez informal formation and consist of sandstone, limestone and dolomitic limestone. One of the most comprehensive outcrops of Hermez Formation is situated in Darin section and is $65.5 \mathrm{~m}$ thick. According to the carbonate composition of the rocks in this formation, accompanied by siliciclastic deposits (sandstone of unite 1), deposits of this formation are formed in a warm and humid climate and close to the siliciclastic deposits supply. Investigating the lithofacies of the deposits of Hermez Formation in Darin section resulted in identifying 1 siliciclastic petrofacies and 14 carbonate microfacies. Regarding microscopic and field observations, siliciclastic petrofacies and carbonate microfacies of this section, facing sea from the coast, include: tidal flat environment, lagoon environment, shoal environment and open marine environment. The vertical and lateral changes of microfacies and comparing them with late and early depositional environments indicate that lack of calciturbidite deposits, slumps, barrier reef and oncolite and presence of gradational facies have caused the mentioned deposits to be formed in a low-angle homoclinal ramp, mostly in the inner ramp, located in the passive margin of southern Paleo-Tethys Ocean.

\section{References}

[1] Aghanabati, A. (2004) Geology of Iran. Geological Survey of Iran, Tehran, 606 p.

[2] Aghanabati, A. (1977) Etudgeologique de la region de Kalmard (W. Tabas). Vol. 35, Geological Survey of Iran, Tehran, 51-63.

[3] Azhdari, A. (1999) Geological Map and Report of Robate-Khan, on Scale of 1:100000. Geological Survey of Iran, Tehran.

[4] Dickson, J. (1965) A Modified Staining Technique for Carbonate in Thin Section. Nature, 205, 587.

[5] Folk, R.L. (1974) Petrology of Sedimentary Rocks. Hemphill Publishing Company, Austin, 182.

[6] Dunham, R.J. (1962) Classification of Carbonate Rocks According to Depositional Texture. In: Ham, W.E., Ed., Classification of Carbonate Rocks: A Symposium, AAPG, Tulsa, No. 1, 108-121.

[7] Embry, A.F. and Klovan, J.E. (1971) A Late Devonian Reef Tract on Northeastern Banks Island. Canadian Petroleum Geology, 19, 730-781.

[8] Wilson, J.L. (1975) Carbonate Facies in Geologic History. Springer, New York, 471. https://doi.org/10.1007/978-1-4612-6383-8

[9] Carozzi, A.V. (1989) Carbonate Rocks Depositional Model. Prentice Hall, Upper Saddle River, 604.

[10] Tucker, M.E. and Wright V.P. (1990) Carbonate Sedimentology. Blackwell Science Ltd., Oxford, 496. https://doi.org/10.1002/9781444314175

[11] Flügel, E. (2010) Microfacies of Carbonate Rocks, Analysis, Interpretation and Application. Springer-Verlag, Berlin, 996. 
[12] Bardossy, G. (1982) Karst Bauxites, Bauxite Deposits on Carbonate Rocks, Developments in Economic Geology. Vol. 14, Elsevier, Amsterdam, 441.

[13] Ozlo, N. (1983) Trace-Element Content Karst Bauxites and Their Parent Rock in the Mediterranean Belt. Mineralium Deposita, 18, 469-476.

[14] Shinn, A. (1983) Tidal Flat Environment. In: Schlle, P.A., Debout, D.G. and Moore, C.H., Eds., Carbonate Depositional Environment, Vol. 33, AAPG, Tulsa, 173-210.

[15] Adabi, M.H., Salehi, M.A. and Ghabeishavi, A. (2010) Depositional Environment, Sequence Stratigraphy and Geochemistry of Lower Cretaceous Carbonates (Fahliyan Formation), South-West Iran. Journal of Asian Earth Sciences, 39, 148-160. https://doi.org/10.1016/j.jseaes.2010.03.011

[16] Adabi, M.H., Kakemem, U. and Sadeghi, A. (2015) Sedimentary Facies Depositional Environment and Sequence Stratigraphy of Oligocene-Miocene Shallow Water Carbonate from the Rig Mountain, Zagros Basin (SW Iran). Carbonates and Evaporites, 31, 69-85.

[17] Butler, G.P., Harris, P.M. and Kendall, C.G. (1982) Recent Evaporites from the Abu-Dhabi Coastal Flats. In: Handford, C.R., Loucks, R.G. and Davies, G.R., Eds., Deposition and Diagenetic Spectra of Evaporites, Society for Sedimentary Geology, Tulsa, No. 3, 33-64. https://doi.org/10.2110/cor.82.01.0033

[18] Warren, J.K. (1989) Reservoir Analysis and Prediction in Carbonate Sequence Course. National Center Petroleum Geology and Geophysics, Adelaide, 164-205.

[19] Adabi, M.H. (2009) Multistage Dolomitization of Upper Jurassic Mozduran Formation, Kopet-Dagh Basin, n.e. Iran. Carbonates and Evaporites, 25, 145-160.

[20] Adabi, M.H. (2012) Sedimentary Geochemistry. 2nd Edition, Arian Zamin Publication, Tehran, 504.

[21] Bachmann, M. and Hirisch, F. (2006) Lower Cretaceous Carbonate Platform of the Eastern Levant (Galilee and the Golan Heights): Stratigraphy and Second-Order Sea-Level Change. Cretaceous Research, 27, 487-512. https://doi.org/10.1016/j.cretres.2005.09.003

[22] Brandano, M., Frezza, V., Tomassetti, L. and Pedley, M. (2010) Facies Analysis and Paleoenvironmental Interpretation of the Late Oligocene Attard Member (Lower Coralline Limstone Formation) Malta. Sedimentalogy, 56, 1138-1158. https://doi.org/10.1111/j.1365-3091.2008.01023.x

[23] Jamalain, M. and Adabi, M.H. (2015) Geochemistry, Microfacies and Diagenetic Evidences for Original Aragonite Mineralogy and Open Diagenetic System of Lower Cretaceous Carbonates Fahliyan Formation (kuh-e siah) Area, Zagros Basin, South Iran. Carbonates and Evaporites, 30, 77-98. https://doi.org/10.1007/s13146-014-0211-8

[24] Boudagher-Fadel, M.K. and Lokier, S.W. (2005) Significant Miocene Larger Foraminifera from South Central Java. Revue de Paleobiologie Geneve, 24, 291-309.

[25] Basso, D., Nalin, R. and Nelson, C.S. (2009) Shallow-Water sporolithonrhodoliths from North Island (New Zealand). Palaios, 24, 92-103. https://doi.org/10.2110/palo.2008.p08-048r

[26] Nebelsick, J.H., Rasser, D. and Lempp, J. (2012) Tracking paleoenvironmental Changes in Coralline Algal-Dominated Carbonates of the Lower Oligocene Calcareniti di Castelgomberto Formation (MontiBerici, Italy). Facies, 59, 133-148. https://doi.org/10.1007/s10347-012-0349-6

[27] Ahmad, A.H.M., Bhat, G.M. and HarisAzim Khan, M. (2006) Depositional Environments and Diagenesis of the Kuldhar and Keera Dome Carbonates (Late Bathonian-Early Callovian) of Western India. Journal of Asian Earth Sciences, 27, 765- 
778. https://doi.org/10.1016/j.jseaes.2005.06.013

[28] Betzler, C., Braga, J.C., Martin, J.M., Sanchez-Almazo, I.M. and Lindhorst, S. (2006) Closure of Aseaway: Stratigraphic Record and Facies (Guadix Basin, Southern Spain). International Journal of Earth Sciences, 95, 903-910. https://doi.org/10.1007/s00531-006-0073-y

[29] Palma, R.M., Lopez Gomez, J. and Piethe, R.D. (2007) Oxfordian Ramp System (La Manga Formation) in the Bardas Area (Mendoza Province), Neuquen Basin, Argantina: Facies and Depositional Sequence. Sedimentary Geology, 195, 113-134. https://doi.org/10.1016/j.sedgeo.2006.07.001

[30] Khatibi, M. and Adabi, M.H. (2013) Microfacies and Geochemical Evidence for Original Aragonite Mineralogy of a Forminifera-Dominated Carbonate Ramp System in the Late Paleocene to Middle Eocene, Alborz Basin, Iran. Carbonates and Evaporites, 29, 155-175.

[31] Mass, J., Fenerci, M. and Pernarcic, E. (2003) Palaeobathymetric Reconstruction of Peritidal Carbonates, Late Barremian, Urgonian, Sequences of Provence (SE France). Palaeogeography, 200, 65-81. https://doi.org/10.1016/S0031-0182(03)00445-0

[32] Sandullia, R. and Raspinib, A. (2004) Regional to Global Correlation of Lower Cretaceous Shallow-Water Carbonates of the Southern Apennines and Dinarides, Southern Tethyan Margin. Sedimentary Geology, 165, 117-153. https://doi.org/10.1016/j.sedgeo.2003.11.014

[33] Koehrer, B., Aigner, T. and Poeppelreiter, M. (2011) Field-Scale Geometries of Upper Khuff Reservoir Geobodies in an Outcrop Analogue (Oman Mountains, Sultanate of Oman). Petroleum Geoscience, 17, 3-16. https://doi.org/10.1144/1354-079310-009

[34] Maurer, F., Martini, R., Rettori, R., Hillgartner, H. and Cirilli, S. (2009) The Geology of Khuff Outcrop Analogues in the Musandam Peninsula, United Arab Emirates and Oman. Geo Arabia, 14, 125-158.

[35] Lasemi, Y. (1995) Platform Carbonate of the Upper Jurassic Mozduran Formation in the Kopet-Dagh Basin, NE Iran, Facies Paleoenvironment and Sequences. Sedimentary Geology, 99, 151-164. https://doi.org/10.1016/0037-0738(95)00041-6

[36] Adachi, N., Ezaki, Y. and Liu, J. (2004) The Origin of Peloids Immediately after the End Permian Extinction, Guizhou Province, South China. Sedimentary Geology, 146, 161-178. https://doi.org/10.1016/j.sedgeo.2003.10.007

[37] Read, J.F. (1985) Carbonate Platform Facies Models. AAPG Bulletin, 69, 1-21.

[38] Tucker, M.E. (2008) Sedimentary Petrology. 3rd Edition, Blackwell Publishing, Oxford, 262.

[39] Berberian, M. and King, G.C. (1981) Toward a Paleogeography and Tectonic Evolution of Iran. In: Berberian, M., Ed., Continental Deformation in the Iranian Plateau, Report No. 52, Geological Survey of Iran, Tehran, 502-530. 
Submit or recommend next manuscript to SCIRP and we will provide best service for you:

Accepting pre-submission inquiries through Email, Facebook, LinkedIn, Twitter, etc. A wide selection of journals (inclusive of 9 subjects, more than 200 journals)

Providing 24-hour high-quality service

User-friendly online submission system

Fair and swift peer-review system

Efficient typesetting and proofreading procedure

Display of the result of downloads and visits, as well as the number of cited articles Maximum dissemination of your research work

Submit your manuscript at: http://papersubmission.scirp.org/

Or contact ojg@scirp.org 